\title{
Functional Acrylic Polymer as Corrosion Inhibitor of Carbon Steel in Autoclaved Air-Foamed Sodium Silicate-Activated Calcium Aluminate/Class F Fly Ash Cement
}

\author{
Toshifumi Sugama, Tatiana Pyatina \\ Sustainable Energy Technologies Department, Brookhaven National Laboratory, Upton, USA \\ Email: sugama@bnl.gov
}

Received September 4, 2013; revised October 4, 2013; accepted October 11, 2013

Copyright (C) 2013 Toshifumi Sugama, Tatiana Pyatina. This is an open access article distributed under the Creative Commons Attribution License, which permits unrestricted use, distribution, and reproduction in any medium, provided the original work is properly cited.

\begin{abstract}
The study focused on investigating the effectiveness of functional acrylic polymer (AP) in improving the ability of airfoamed sodium silicate-activated calcium aluminate/Class F fly ash cement (slurry density of $\leq 1.3 \mathrm{~g} / \mathrm{cm}^{3}$ ) to mitigate the corrosion of carbon steel (CS) after exposure to hydrothermal environment at $200^{\circ} \mathrm{C}$ or $300^{\circ} \mathrm{C}$. Hydrothermally-initiated interactions between the AP and cement generated the formation of Ca-, Al-, or Na-complexed carboxylate derivatives that improved the AP's hydrothermal stability. A porous microstructure comprising numerous defect-free, evenly distributed, discrete voids formed in the presence of this hydrothermally stable AP, resulting in the increase in compressive strength of cement. The foamed cement with advanced properties conferred by AP greatly protected the CS against brine-caused corrosion. Four major factors governed this protection by AP-incorporated foamed cements: 1) Reducing the extents of infiltration and transportation of corrosive electrolytes through the cement layer deposited on the underlying CS surface; 2) Inhibiting the cathodic reactions at the corrosion site of CS; 3) Extending the coverage of CS by the cement; and 4) Improving the adherence of the cement to CS surface.
\end{abstract}

Keywords: Calcium Aluminate Foamed Cement; Thermal Shock Resistance; Corrosion Protection; Carbon Steel

\section{Introduction}

The major thrust in assembling and constructing Enhanced Geothermal Systems (EGSs) lies in creating a hydrothermal reservoir in a hot dry rock stratum $\geq 200^{\circ} \mathrm{C}$, located at $\sim 3-10 \mathrm{~km}$ below the ground surface. In this operation, water at a low temperature of $\sim 25^{\circ} \mathrm{C}$ is pumped down the injection well to initiate the opening of existing fractures. Multi-injection wells are required to create a desirable network of permeable fractures. After that, a production well is installed within the fracture's network.

During the water injection, considerable attention must be paid to a significant differential between the temperatures at the bottom of the well and of the water from the injection well. This differential leads to a sudden temperature drop of $\geq \sim 180^{\circ} \mathrm{C}$ at the cement sheath surrounding the down-hole casing. Such a large thermal gradient due to the cooling effect of the injection water can give an undesirable thermal stress to the cement sheath, causing its potential failure that will entail a catastrophic blowout of the well. To mitigate such temperature differential-caused stresses, the cement placed in EGS is required to possess adequate resistances to thermal cycle fatigue and thermal shock.

To deal with this issue and develop thermal shock-resistant cements, our previous study investigated the effectiveness of sodium silicate-activated Class F fly ash in improving such resistance of refractory calcium aluminate cement (CAC) [1]. We conducted a multiple air heating $\left(500^{\circ} \mathrm{C}\right)$-water $\left(25^{\circ} \mathrm{C}\right)$ cooling quenching cycle tests for evaluating thermal shock resistance of $200^{\circ} \mathrm{C}$ autoclaved CAC/Class $\mathrm{F}$ fly ash/sodium silicate blend cements. The phase composition of the autoclaved CAC/ Class F fly ash blend cements comprised four crystalline hydration products, boehmite, katoite, hydrogrossular, and hydroxysodalite, which were responsible for 
strengthening cement. Among them, the hydroxysodalite was transformed into nano-scale crystalline carbonated sodalite during this cycle test. This phase transition not only played a pivotal role in densifying cementitious structure and in sustaining the original compressive strength developed after autoclaving, but also it improved the CAC's resistance to thermal shock.

Another critical issue in formulating well casing cements is the density of the cement slurry. Cement slurry of a typical density, $1.8-2.0 \mathrm{~g} / \mathrm{cm}^{3}$, may create undesirable fractures zones in a weak unconsolidated rock formation due to the high hydrostatic pressure needed for its circulation and cause an issue of lost circulation. Thus, it is vital to use cement slurry with the minimum density possible for lowering this hydrostatic pressure. However, our study of the properties of fine air bubble-incorporated foamed cement slurry strongly suggested that the shortcoming of this hydrothermally cured foamed cement was its low protection of carbon steel (CS) casings against corrosion, compared with that of non-foamed cement [2].

As is well documented [3-8], when the surfaces of CS come in contact with alkaline pore solution of $\mathrm{pH}>12$ in Ordinary Portland Cement (OPC), they form a passive $\mathrm{Fe}$ oxide film that protects the CS against corrosion. However, the stability of this passivation layer depends primarily on the surrounding environment and exposure conditions. In geothermal environments, there are two major chemical factors governing the destruction of the corrosion-preventing passive film and initiation of casing corrosion: One is the prevalence of carbonation-related carbonate ions; and, the other is the attack of chloride ions on the passive film in which the risk of corrosion of CS commonly is equated with the chloride content, usually taking into account the chloride/hydroxyl $\left[\left(\mathrm{Cl}^{-}\right) /\right.$ $\left.\left(\mathrm{OH}^{-}\right)\right]$ratio. For the former factor, carbon dioxide $\left(\mathrm{CO}_{2}\right)$ can penetrate into the pores in $\mathrm{OPC}$, and then react with water to form carbonic aid, $\mathrm{H}_{2} \mathrm{CO}_{3}$, thereby lowering the $\mathrm{pH}$ of the pore solution in OPC layers adjacent to the CS's surfaces. Thus, such depassivation promotes the localized corrosion of CS, and then, the corrosion products formed on CS's surface engender a volumetric expansion of CS, generating a stress cracking and the spallation of OPC sheath at the interfacial boundary regions between the OPC and CS-based well casing. Further, the failure of OPC sheath at the initial stage of CS's corrosion not only accelerates its corrosion rate, but also shortens the service lifespan of casings; such impairment of the integrity of well structure entails the need for costly repairs and restorative operations including redrilling to reconstruct the damaged well, and occasionally necessitates the assemblage of new wells. To avoid such catastrophic failure of well structure, very expensive metal components incurring a high capital investment, for example, titanium alloy, stainless steel, and inconel components frequently are employed in fabricating corrosion-preventing well casings. Thus, the ideal approach to reducing capital investments along with the operational- and maintenance-costs in EGS wells is using inexpensive CS-based casings covered with corrosioninhibiting well cementing materials. In this concept, the cementing materials play a pivotal role in extending the lifecycles of the CS-made casings and in retaining the well's integrity, so eventually lowering the costs of electricity generated from geothermal power plants.

Presently, there are two prevalent methods to minimize and alleviate the corrosion of CS [9,10]: The first one is to apply coatings to CS's surface as cathodic protection; the other is to use anodic corrosion inhibitors. Our previous work on the former method [11] centered on evaluating the ability of a hybrid coating system consisting of a water-borne acrylic emulsion as the matrix and $\mathrm{CAC}$ as the hydraulic binder to mitigate the corrosion of $\mathrm{CS}$ in $\mathrm{CO}_{2}$-laden geothermal environments at $250^{\circ} \mathrm{C}$. We identified two major factors that significantly contributed to inhibiting the corrosion of CS in such hydrothermal environment: One was the hydrothermally stable products formed by the interactions between acrylic polymer and cement; the other was the development of a dense microstructure by the combination of well-formed calcite and boehmite crystals with polymer-cement reaction products.

Based upon this information, the CAC/Class F fly ash/ sodium silicate blend cements, formulated as the thermal shock-resistant cement (TSRC), would be required to possess two indispensable properties: First, the slurry density must be lowered; and, second, the ability of hydrothermally cured TSRC to protect the CS casing against corrosion must be assured. Hence, we formulated air bubble-foamed TSRC for preparing low density cement slurry at room temperature, and then the foamed TSRC was modified with acrylic-based polymer emulsion as corrosion-inhibiting additive to lessen the corrosion of CS under a hydrothermal environment at $200^{\circ} \mathrm{C}$ and $300^{\circ} \mathrm{C}$. In characterizing the polymer-modified foamed TSRC, our study focused on eight major objecttives: 1) Characterizing the hydrolysis-hydration reactions of the cement slurries at $85^{\circ} \mathrm{C}$ and assessing the total energy evolved during these reactions; 2) identifying the reaction product formed by interactions between cement and acrylic-based polymer (AP) at $200^{\circ} \mathrm{C}$ and $300^{\circ} \mathrm{C}$, and assessing its thermal stability; 3 ) determining the compressive strength of $200^{\circ} \mathrm{C}$ - and $300^{\circ} \mathrm{C}$-autoclaved cements; 4) identifying the crystalline phases and their composition formed in the cement after autoclaving at $200^{\circ} \mathrm{C}$ and $300^{\circ} \mathrm{C}$; 5) exploring the microstructure developed within the cements; 6) measuring the conductivity of corrosive ions through the cement layers deposited on the CS's surfaces by the AC electrochemical im- 
pedance spectroscopy; 7) evaluating the ability of cement coating to reduce the corrosion rate of CS using the DC electrochemical potentiodynamic polarization; and 8) assessing the extent of adherence of the cements to the underlying CS.

Integrating all the data obtained from the objectives described above would clarify the potential of the APmodified foamed TSRC as corrosion-alleviating well cement for CS casings in EGS environment at $200^{\circ} \mathrm{C}$ and $300^{\circ} \mathrm{C}$

\section{Experimental Procedures}

\subsection{Materials}

Class F fly ash was obtained from Boral Material Technologies, Inc., and its chemical composition detected by micro energy-dispersive X-ray spectrometer ( $\mu \mathrm{EDX})$ was as follows; $50.4 \% \mathrm{SiO}_{2}, 34.8 \% \mathrm{Al}_{2} \mathrm{O}_{3}, 7.1 \% \mathrm{Fe}_{2} \mathrm{O}_{3}, 3.1 \%$ $\mathrm{K}_{2} \mathrm{O}, 2.7 \% \mathrm{CaO}, 1.6 \% \mathrm{TiO}_{2}$, and $0.4 \% \mathrm{SO}_{3}$. A sodium silicate granular powder under the trade name "Metso Beads 2048," supplied by the PQ Corporation was used as the alkali activator of Class $\mathrm{F}$ fly ash. Its chemical composition was $50.5 \mathrm{wt} \% \mathrm{Na}_{2} \mathrm{O}$ and $46.6 \mathrm{wt} \% \mathrm{SiO}_{2}$. Secar \#80, supplied by Kerneos Inc. was used as refracttory calcium aluminate cement (CAC). The X-ray powder diffraction (XRD) data showed that the crystalline compounds of Class $\mathrm{F}$ fly ash had three major phases, quartz $\left(\mathrm{SiO}_{2}\right)$, mullite $\left(3 \mathrm{Al}_{2} \mathrm{O}_{3} \cdot 2 \mathrm{SiO}_{2}\right)$, and hematite $\left(\mathrm{Fe}_{2} \mathrm{O}_{3}\right)$, while CAC encompassed three crystalline phases, corundum $\left(\alpha-\mathrm{Al}_{2} \mathrm{O}_{3}\right)$, calcium monoaluminate

$\left(\mathrm{CaO} \cdot \mathrm{Al}_{2} \mathrm{O}_{3}, \mathrm{CA}\right)$, and calcium dialuminate $\left(\mathrm{CaO} \cdot 2 \mathrm{Al}_{2} \mathrm{O}_{3}\right.$, $\mathrm{CA}_{2}$ ).

The AISI 1008 cold rolled steel test panel according to ASTM D 609C was used as the carbon steel (CS) substrate, supplied by ACT Test Panels, LLC. An alkaline cleaner \#4429, from American Chemical Products, was employed to remove surface contaminants from it. This cleaner was diluted with deionized water to prepare 5 wt $\%$ cleaning solution.

Acrylic emulsion under the trade name "HYCAR ${ }^{\circledR} 26-$ 0688," supplied by Lubrizol, was evaluated as the corrosion-inhibiting additive for cement. This water-disperseble acrylic emulsion consisted of $49.5 \mathrm{wt} \%$ solid acrylic polymer (AP) and $41.5 \mathrm{wt} \%$ aqueous medium, and its $\mathrm{pH}$ was 2.32 .

Halliburton supplied the cocamidopropyl dimethylamine oxide-based foaming agent (FA) under the trade name "ZoneSealant 2000."

The formula of dry-blend cement employed in this study consisted of $60 \mathrm{wt} \% \mathrm{CAC}$ and $40 \mathrm{wt} \%$ Class $\mathrm{F}$ fly ash. The sodium silicate at $6.2 \%$ by total weight of the blended cement was added to 60/40 CAC/Class F fly ash ratio to prepare the one dry-mix cement component. The amounts of AP used to modify the cement were $0.5,1.0$, and $2.0 \%$ by total weight of this dry mixture. The FA was added at $1.0 \%$ by total weight of water. The following sequence was employed to make the foamed APcontaining cement slurry: First, the proper amount of water-miscible FA was blended in water, and then the proper amount of acrylic emulsion was incorporated into it; second, this water-based solution was added to the dry cement component to prepare a pumpable slurry; the water/(cement + acrylic emulsion) $[\mathrm{W} /(\mathrm{C}+\mathrm{AE})]$ ratios for $0,0.5,1.0$, and $2.0 \mathrm{wt} \% \mathrm{AP}$-modified cements were $0.44,0.37,0.28$, and 0.15 , receptivity; and, finally, the AP-containing foamed cement slurry was mixed thoroughly in a shear-blender for $30 \mathrm{sec}$. This shear mixing made it possible to prepare aerated slurry containing a vast number of air bubbles, leading to the transformation of the original stiff slurry into a smooth creamy one.

The surfaces of the $65 \mathrm{~mm} \times 65 \mathrm{~mm}$ CS test panels were coated with the foamed AP-containing cements in the following sequence: First, the "as-received" test panels were immersed in a $5 \mathrm{wt} \%$ alkali-cleaning solution at $40^{\circ} \mathrm{C}$ for $10 \mathrm{~min}$; second, alkali-cleaned panels' surfaces were rinsed with a tap water at $25^{\circ} \mathrm{C}$, and dried for 24 hours in air at room temperature; third, the panels were dipped into a soaking bath of cement slurries at room temperature, and withdrawn slowly; fourth, the cement slurry-covered panels were left for 3 days at room temperature, allowing the slurry to convert into a solid layer; and, finally, the cement-coated panels were autoclaved for 24 hours at $200^{\circ} \mathrm{C}$ and $300^{\circ} \mathrm{C}$ before conducting the electrochemical corrosion tests. The thickness of the deposited cement layers on the CS's surfaces ranged from $\sim 1.0$ to $\sim 1.4 \mathrm{~mm}$.

\subsection{Measurements}

The density, $\mathrm{g} / \mathrm{cm}^{3}$, of the foamed cement slurries was determined using the fluid density container. Then, the slurries were poured in cylindrical molds $(20 \mathrm{~mm}$ diam. and $40 \mathrm{~mm}$ long) and left for 3 days at room temperature before compressive strength measurements. Thereafter, the hardened foamed cements were removed from the mold and autoclaved at $200^{\circ} \mathrm{C}$ and $300^{\circ} \mathrm{C}$ for 24 hours, then left for 24 hours at room temperature.

TAM Air Isothermal Microcalorimeter was adapted to investigate the hydrolysis-hydration reactions in cement slurries and to determine the cumulative heat flow evolved during these reactions at $85^{\circ} \mathrm{C}$. The changes in compressive strength of the $200^{\circ} \mathrm{C}$ - and $300^{\circ} \mathrm{C}-24 \mathrm{~h}$ autoclaved cements as a function of AP's content were obtained using Instron Model 5967. The reaction products between the AP and cement at hydrothermal temperatures of $85^{\circ} \mathrm{C}, 200^{\circ} \mathrm{C}$, and $300^{\circ} \mathrm{C}$ were identified using Fourier Transform Infrared Spectroscopy (FT-IR), and then the thermal stability of identified reaction products was surveyed using Thermo Gravimetric Analyzer 
(TGA) at the heating rate of $20^{\circ} \mathrm{C} / \mathrm{min}$ in a $\mathrm{N}_{2}$ flow. The composition of crystalline phases formed in $200^{\circ} \mathrm{C}$ - and $300^{\circ} \mathrm{C}$-autoclaved foamed cements was identified by $\mathrm{X}$ ray diffraction (XRD). Alterations of the microstructure developed in foamed cements at $200^{\circ} \mathrm{C}$ by AP were explored with the High-Resolution Scanning Electron Microscopy (HR-SEM). The adherence behavior of APmodified and non-modified foamed cements to CS's surface was surveyed using $\mu \mathrm{EDX}$. DC electrochemical testing for corrosion of the underlying CS was performed with the EG\&G Princeton Applied Research Model 326-1 Corrosion Measurement System. For this assessment, the cement-coated CS specimen was mounted in a holder, and then inserted into an EG\&G Model K47 electrochemical cell containing a $1.0 \mathrm{M}$ sodium chloride electrolyte solution. The test was conducted under an aerated condition at $25^{\circ} \mathrm{C}$, on an exposed surface area of $1.0 \mathrm{~cm}^{2}$. The polarization curves were measured at a scan rate of $0.5 \mathrm{mVs}^{-1}$ in the corrosion potential range from -0.05 to $-0.75 \mathrm{~V}$. AC electrochemical impedance spectroscopy (EIS) was used to evaluate the ability of the cement layers to protect the CS from corrosion. For this, the coated CS specimens with a surface area of $13 \mathrm{~cm}^{2}$ were mounted in a holder, and then inserted into an electrochemical cell containing a $1.0 \mathrm{M}$ sodium chloride electrolyte at $25^{\circ} \mathrm{C}$; single-sine technology with an input AC voltage of $10 \mathrm{mV}$ (rms) was employed over a frequency range of $10^{5}$ to $10^{-3} \mathrm{~Hz}$. To estimate the protective performance of the cements, the pore resistance, $R_{p}$, $\left(\mathrm{ohm}-\mathrm{cm}^{2}\right)$ was determined from the plateau in Bode-plot scans occurring in low frequency regions.

\section{Results and Discussion}

\subsection{Density of Slurries}

Figure 1 shows the changes in slurry density as a function of AP content. Without any AP, the density of the

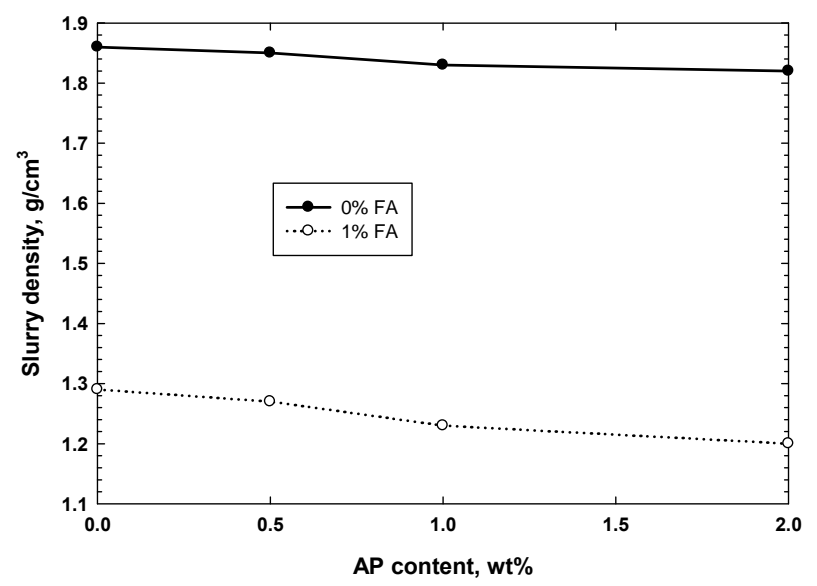

Figure 1. Changes in slurry density for FA-foamed and non-foamed cement slurries as a function of AP content. non-foamed cement slurry denoted as 0\% FA was 1.86 $\mathrm{g} / \mathrm{cm}^{3}$. This density drastically dropped by $31 \%$ to 1.29 $\mathrm{g} / \mathrm{cm}^{3}$, as $1 \%$ FA was added to it, demonstrating that this FA is very effective in and suitable for reducing the density of this specific blend cement slurry. When AP additive was incorporated into non-foamed and foamed slurries, their densities gradually declined with an increasing content of AP; adding $2 \mathrm{wt} \%$ AP reduced the density to $1.82 \mathrm{~g} / \mathrm{cm}^{3}$ for non-foamed and to $1.2 \mathrm{~g} / \mathrm{cm}^{3}$ for foamed slurry, suggesting that AP has air-entraining properties in slurry during mixing.

\subsection{Hydrothermal Stability of AP in Cement}

One inevitable question that must be asked is the susceptibility of AP to the hydrothermal degradation in cement slurries at $200^{\circ} \mathrm{C}$ and $300^{\circ} \mathrm{C}$. To respond to this question, we prepared samples composed of $50 \mathrm{wt} \%$ acrylic emulsion and $50 \mathrm{wt} \% \mathrm{CAC} / \mathrm{Class} \mathrm{F}$ fly ash/sodium silicate blend cement at room temperature, and then autoclaved them for 24 hours at $85^{\circ} \mathrm{C}, 200^{\circ} \mathrm{C}$, and $300^{\circ} \mathrm{C}$, to conduct FT-IR and TGA analyses. The "as-received" acrylic emulsion was used as the control for FT-IR analysis.

Figure 2 shows the FT-IR spectra over frequency range from 1850 to $1250 \mathrm{~cm}^{-1}$, for the control, and APs formed in $85^{\circ} \mathrm{C}$-, $200^{\circ} \mathrm{C}$-, and $300^{\circ} \mathrm{C}$-autoclaved cements. The absorbance spectrum of $85^{\circ} \mathrm{C}$-autoclaved sample encompassed four prominent bands: At $1730 \mathrm{~cm}^{-1}$ attributed to the acrylic acid, - $\mathrm{COOH}$, and alkyl ester, -COOR ( $\mathrm{R}$, ethyl or butyl ester); at 1552 and $1405 \mathrm{~cm}^{-1}$ corresponding to the symmetric and anti-symmetric stretching, respectively, of the carboxylate anion, $-\mathrm{COO}^{-}$in $-\mathrm{COO}^{-}$ $\mathrm{M}$ (M, metallic cations) linkage structure; and, at 1452 $\mathrm{cm}^{-1}$ associating with $\mathrm{CO}_{3}{ }^{2-}$ in carbonated compounds. In comparison, no bands related to carboxylate anion were found in the control. The spectrum of $200^{\circ} \mathrm{C}$-ex-

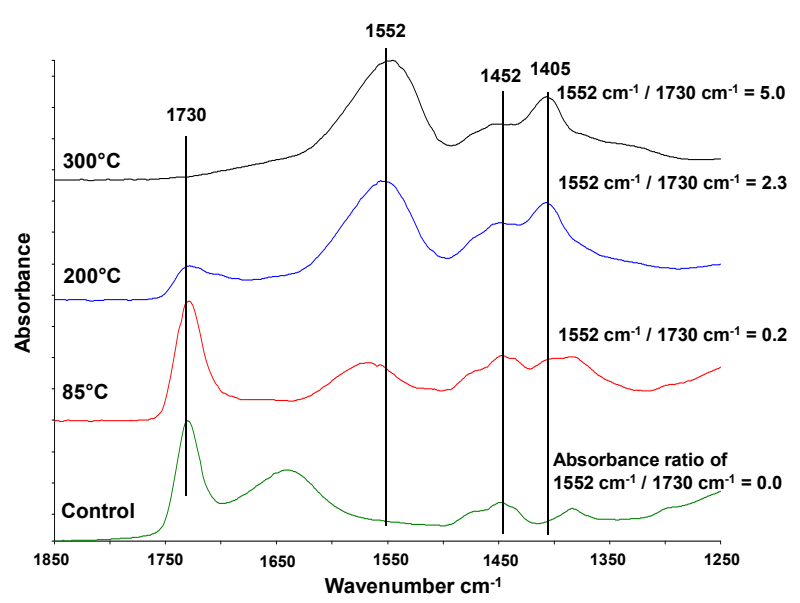

Figure 2. Comparison of FT-IR spectral features and absorbance ratios of $1552 \mathrm{~cm}^{-1}$ to $1730 \mathrm{~cm}^{-1}$ bands for control AP and $A P$ autoclaved in cement slurry at $85^{\circ} \mathrm{C}, 200^{\circ} \mathrm{C}$ and $300^{\circ} \mathrm{C}$. 
posed sample displayed two features different from the sample exposed to $85^{\circ} \mathrm{C}$ : One was a striking decay in the intensity of band at $1730 \mathrm{~cm}^{-1}$; the other was the marked growth of the absorbance bands at 1552 and $1405 \mathrm{~cm}^{-1}$.

This fact strongly suggested that raising the hydrothermal temperature promoted the transformation of acrylic acid and alkyl ester within the molecular structure of AP into the carboxylate anion derivative. This transformation was further enhanced as the temperature rose to $300^{\circ} \mathrm{C}$, reflecting a near disappearance of the band at $1730 \mathrm{~cm}^{-1}$. To support this information, we compared the absorbance ratios of $1552 \mathrm{~cm}^{-1}$ to $1730 \mathrm{~cm}^{-1}$ for the control, and $85^{\circ} \mathrm{C}, 200^{\circ} \mathrm{C}$, and $300^{\circ} \mathrm{C}$ samples (Figure 2). For the control, it was very difficult to determine the $\mathrm{ab}$ sorbance at $1552 \mathrm{~cm}^{-1}$. The $85^{\circ} \mathrm{C}$ sample had an absorbance ratio of 0.2 , strongly verifying that the reactions between AP and cement already had occurred at such a relatively lower temperature. As expected, the value of this ratio increased with an increasing autoclave temperature; at $300^{\circ} \mathrm{C}$, the ratio of 5.0 was twenty five fold greater than that at $85^{\circ} \mathrm{C}$. These results clearly validated that the acrylic acid or alkyl ester $\rightarrow$ carboxylate anions transformation occurred progressively at elevated hydrothermal temperatures.

One important criterion of a high-temperature corrosion inhibitor is its stability at $\geq 200^{\circ} \mathrm{C}$. Hence, our attention next focused on surveying the thermal stability of AP derivatives obtained in high-temperature hydrothermal reactions. The same samples as those used in the previous FT-IR analysis were dried for 24 hours at $85^{\circ} \mathrm{C}$ to eliminate any free moisture and tested by TGA. Figure 3 depicts the TGA curves between $25^{\circ} \mathrm{C}$ and nearly $500^{\circ} \mathrm{C}$ for the $85^{\circ} \mathrm{C}$-, $200^{\circ} \mathrm{C}$-, and $300^{\circ} \mathrm{C}$-autoclaved samples. The major thermal decomposition of AP formed in $85^{\circ} \mathrm{C}$-autoclaved samples occurred around $300^{\circ} \mathrm{C}$. Decomposition temperature of AP in $200^{\circ} \mathrm{C}$-autoclaved sample increased to $\sim 349^{\circ} \mathrm{C}$, which was $\sim 49^{\circ} \mathrm{C}$ higher than for $85^{\circ} \mathrm{C}$ sample.

The decomposition temperature further increased to

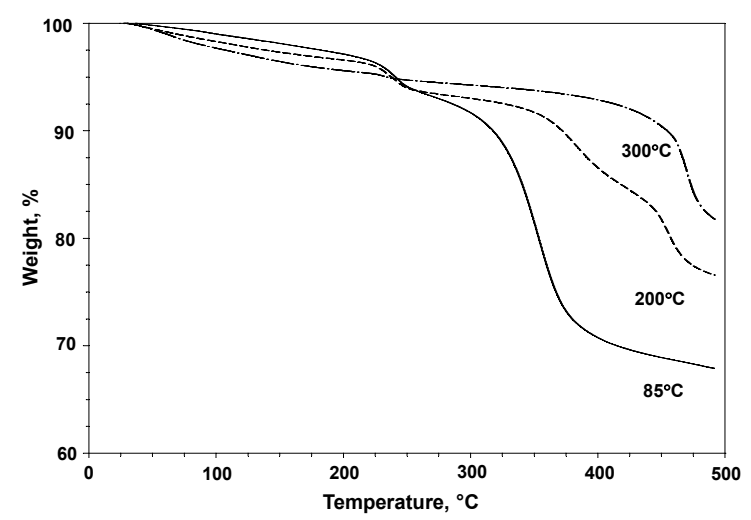

Figure 3. Thermal decomposition curves of AP autoclaved in cement slurry at $85^{\circ} \mathrm{C}, 200^{\circ} \mathrm{C}$ or $300^{\circ} \mathrm{C}$. $\sim 438^{\circ} \mathrm{C}$ for AP from $300^{\circ} \mathrm{C}$-autoclaved sample.

Combined results of FT-IR and TGA studies highlighted that the hydrothermal stability of AP in autoclaved cement was improved by incorporating more Metal-complexed carboxylate structures at $300^{\circ} \mathrm{C}$, compared to AP autoclaved in cement at $200^{\circ} \mathrm{C}$. Thus the AP in cement withstood the $300^{\circ} \mathrm{C}$ hydrothermal environment.

\subsection{Hydration of AP-Modified Foamed Cement}

To investigate the changes in cement hydration with addition of FA, AP or both we measured heat flow evolved at the isothermal temperature of $85^{\circ} \mathrm{C}$ during cement hydration as a function of elapsed time.

Figure 4 depicts relations between the normalized heat flow energy and elapsed time for non-foamed and foamed cement slurries without AP. For all the samples, the initial heat release peak denoted as the peak No. 1, corresponds to the particle wetting, dissolution of sodium silicate activator, beginning of the hydrolysis of some CAC and Class F fly ash by the alkali activation of dissolved sodium silicate. This peak was observed shortly after placing an ampoule of the sample in a calorimeter with the maximum heat flow (MHF) been reached within 50 min. Subsequently, two other heat peaks marked as No. 2 and No. 3 were traced for both the non-foamed and $1 \mathrm{wt} \%$ FA-foamed slurries. This cement system consisted of two cement-forming reactants, CAC and Class F fly ash, our preliminary study (not shown) demonstrated that the hydration reactions of CAC were much faster than those of Class F fly ash. Thus, in the non-foamed cement slurry, the No. 2 peak emerged at elapsed time of $11 \mathrm{~h} 32$ min was more likely associated with CAC hydration.

It had MHF of $0.83 \mathrm{~mW} / \mathrm{g}$. The Class $\mathrm{F}$ fly ash-related No. 3 peak generated a $0.56 \mathrm{~mW} / \mathrm{g}$ MHF at the elapsed time of $47 \mathrm{~h} 13 \mathrm{~min}$. When non-foamed slurry was modi-

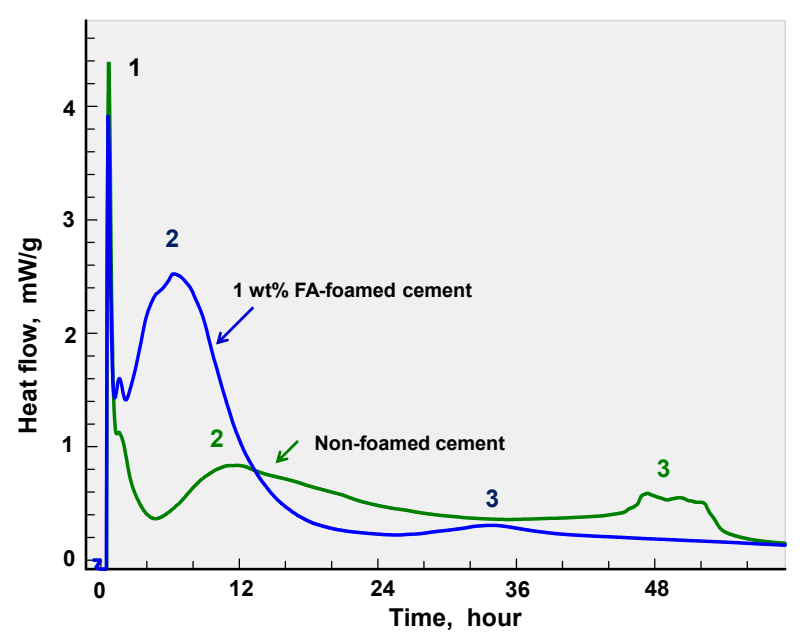

Figure 4. Microcalorimetric curves for non-foamed and 1 wt \% FA-foamed cement slurries at $85^{\circ} \mathrm{C}$. 
fied with 1 wt $\%$ FA, its heat flow-time curve differed in three aspects from that of non-foamed one: First, the time to reach No. 2 and No. 3 peaks became shorter; second, the MHF value of the No. 2 peak increased pronouncedly to $2.52 \mathrm{~mW} / \mathrm{g}$; and, third, the MHF value at No. 3 peak had declined by $\sim 45 \%$ to $0.31 \mathrm{~mW} / \mathrm{g}$. These results suggested that the foaming agent promoted the hydration reactions of $\mathrm{CAC}$, so enhancing $\mathrm{CAC}$-related $\mathrm{MHF}$ energy.

Table 1 lists the elapsed times at the onset and end of No. 2 and No. 3 reactions along with the total energies evolved in these reactions for non-foamed and foamedcement slurries at $85^{\circ} \mathrm{C}$. The total energies were computed from the enclosed areas of the heat flow-elapsed time curves with the baseline extending between peaks' starts and ends. The No. 2 reaction, attributed to CAC's hydration, clearly verified that it was accelerated by adding the $1 \mathrm{wt} \% \mathrm{FA}$. The onset of this reaction was shortened to $1 \mathrm{~h} 59 \mathrm{~min}$ by FA, compared to $4 \mathrm{~h} 6 \mathrm{~min}$ for the FA-free slurry. The computed heat flow energy, $\mathrm{J} / \mathrm{g}$, verified the increase of this energy by FA; in fact, a $40.4 \mathrm{~J} / \mathrm{g}$ generated with $1 \mathrm{wt} \% \mathrm{FA}$ was tantamount to $11.3 \%$ higher than for the non-foamed slurry. Such an effect of FA on CAC reactions accelerated the reactivity of Class F fly ash, thereby shortening the time to reach the onset of the No.3 reaction to $25 \mathrm{~h} 6 \mathrm{~min}$ for $1 \mathrm{wt} \%$ FA from 33 h 53 min required for non-foamed slurry. However, as for the Class F fly ash-related heat release, the contribution of FA to the increase in this energy was minimal; in fact, the value of $11.8 \mathrm{~J} / \mathrm{g}$ for non-foamed slurry declined 1.8 times when $1 \mathrm{wt} \%$ FA was added to it. Nevertheless, the total energy evolved from No. 2 and No. 3 reactions rose with FA.

Next, we obtained information on heat flow-elapsed time relations for the foamed slurries with $0.5,1.0$, and

\section{$2.0 \mathrm{wt} \% \mathrm{AP}$ at $85^{\circ} \mathrm{C}$.}

Table 2 summarizes the elapsed times at the onset and end of each No. 2 and No. 3 reactions along with the total energy evolved from these two reactions for $0,0.5$, 1.0, and $2.0 \mathrm{wt} \%$ AP-modified foamed slurries. As is evident from these data, addition of AP in the concentration range of $0.5-2.0 \mathrm{wt} \%$ pronouncedly retarded the $\mathrm{CAC}$ reaction. The onset time of this reaction for unmodified foamed slurry was delayed by as much as 3 and 5 hours with 1 and $2 \mathrm{wt} \%$ of AP, respectively. In contrast, AP was not as effective in delaying the onset time of Class F fly ash hydration as it was with CAC. On the other hand, the total energy evolved from the No. 2 reaction was strikingly augmented with an increasing AP content, from $33.9 \mathrm{~J} / \mathrm{g}$ for $0 \mathrm{wt} \%$ to $55.8 \mathrm{~J} / \mathrm{g}$ for $2 \mathrm{wt} \%$, for Class F fly ash-associated No. 3 reaction. Hence, AP preferentially retarded the hydration reaction of $\mathrm{CAC}$, rather than that of Class F fly ash. Such augmentation of CAC reaction energy by adding AP could be due to the energy generated by the acid-base interactions between the AP and CAC to form M-complexed carboxylates (Maluminum, calcium, alkali metals) as the reaction products.

\subsection{Compressive Strength}

Figure 5 plots the compressive strength of the $200^{\circ} \mathrm{C}$ and $300^{\circ} \mathrm{C}$-autoclaved foamed cements modified with 0 , $0.5,1.0$, and $2.0 \mathrm{wt} \%$ AP. The value of compressive strength depended on two factors, the content of AP and the hydrothermal temperature. For the latter, cement autoclaved at $300^{\circ} \mathrm{C}$ was more effective in developing the compressive strength, than cement autoclaved at $200^{\circ} \mathrm{C}$.

For the foamed cement without AP, autoclaving at

Table 1. Calorimetric test results for non-foamed, and 1 wt $\%$ FA-foamed cement slurries at $85^{\circ} \mathrm{C}$.

\begin{tabular}{|c|c|c|c|c|c|c|c|}
\hline \multirow{2}{*}{$\mathrm{FA}, \mathrm{wt} \%$} & \multicolumn{3}{|c|}{ No. 2 reaction } & \multicolumn{3}{|c|}{ No. 3 reaction } & \multirow{2}{*}{$\begin{array}{l}\text { Total evolved heat, } \\
\mathrm{J} / \mathrm{g}\end{array}$} \\
\hline & Onset time, $\mathrm{h}: \min$ & End time, $\mathrm{h}: \min$ & Evolved heat, J/g & Onset time, h: $\min$ & End time, $\mathrm{h}: \min$ & Evolved heat, $\mathrm{J} / \mathrm{g}$ & \\
\hline 1 & $1: 59$ & $22: 19$ & 33.9 & $25: 06$ & 48:02 & 6.5 & 40.4 \\
\hline
\end{tabular}

Table 2. Calorimetric test results for No. 2 and 3 reactions with $0,0.5,1.0$, and $2.0 \mathrm{wt} \%$ AP-modified foamed slurries.

\begin{tabular}{|c|c|c|c|c|c|c|c|}
\hline \multirow{2}{*}{$\mathrm{AP}, \mathrm{wt} \%$} & \multicolumn{3}{|c|}{ No. 2 reaction } & \multicolumn{3}{|c|}{ No. 3 reaction } & \multirow{2}{*}{$\begin{array}{c}\text { Total evolved } \\
\text { heat, } \mathrm{J} / \mathrm{g}\end{array}$} \\
\hline & Onset time, $\mathrm{h}: \min$ & End time, h: $\min$ & Evolved heat, $\mathrm{J} / \mathrm{g}$ & Onset time, h: min & End time, h: $\min$ & Evolved heat, J/g & \\
\hline 0.0 & $1: 59$ & $22: 19$ & 33.9 & $25: 06$ & 48:02 & 6.5 & 40.4 \\
\hline 0.5 & $2: 20$ & $22: 49$ & 42.5 & $25: 15$ & $47: 10$ & 7.1 & 49.6 \\
\hline 1.0 & $3: 59$ & $21: 30$ & 47.2 & $25: 46$ & $48: 21$ & 8.8 & 56.0 \\
\hline 2.0 & $5: 33$ & $21: 51$ & 55.8 & $26: 03$ & $45: 35$ & 10.8 & 66.6 \\
\hline
\end{tabular}




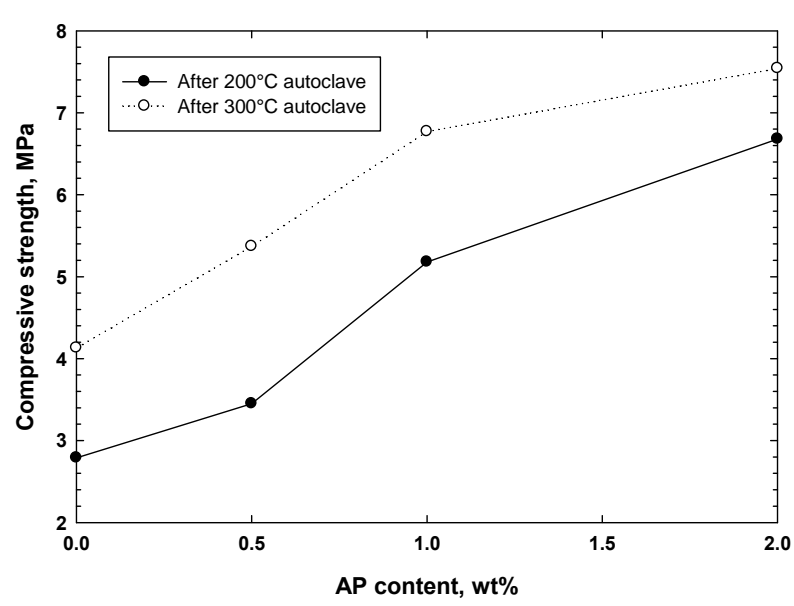

Figure 5. Changes in compressive strength of the $200^{\circ} \mathrm{C}$ and $300^{\circ} \mathrm{C}$-autoclaved foamed cements as a function of AP content.

$200^{\circ} \mathrm{C}$ resulted in a compressive strength of $2.79 \mathrm{MPa}$. This strength rose by 1.5 -fold to $4.13 \mathrm{MPa}$ after autoclaving at $300^{\circ} \mathrm{C}$, so confirming that sodium silicateactivated $\mathrm{CAC} /$ Class $\mathrm{F}$ fly ash blended cement system withstood the hydrothermal temperatures up to $300^{\circ} \mathrm{C}$. Importantly, the rise in compressive strength at $300^{\circ} \mathrm{C}$ reflected the densification of formed cement; in fact, the bulk density of $300^{\circ} \mathrm{C}$-autoclaved cements was $\sim 15 \%$ higher than that one autoclaved at $200^{\circ} \mathrm{C}$.

The presence of AP improved the compressive strength at both $200^{\circ} \mathrm{C}$ and $300^{\circ} \mathrm{C}$; this strength tended to rise progressively with increasing AP content. At $200^{\circ} \mathrm{C}$, adding only $0.5 \mathrm{wt} \%$ AP resulted in the compressive strength increase by $19 \%$ to $3.45 \mathrm{MPa}$. Further increasing AP content to $2.0 \mathrm{wt} \%$ strengthened it more; reaching a value of $6.68 \mathrm{MPa}$, equivalent to 2.4-fold improvement compared with that of AP-free cement. A similar trend was observed from $300^{\circ} \mathrm{C}$-autoclaved foamed cement; adding $2.0 \mathrm{wt} \% \mathrm{AP}$ developed a $7.54 \mathrm{MPa}$ compressive strength, corresponding to 1.4-fold improvements above that of $0.5 \mathrm{wt} \%$ AP. Thus, the AP additive greatly contributed to improving the cement's compressive strength in a hydrothermal environment at $200^{\circ} \mathrm{C}$ and $300^{\circ} \mathrm{C}$.

\subsection{Phase identification and Microstructure Development}

One intriguing question of the incorporation of AP into the autoclaved foamed cement was whether it would change the composition of the crystalline phases as the hydrothermal reaction products responsible for strengthening it. Accordingly, XRD was used to identify the phases assembled in the foamed cements containing 0 and $2 \mathrm{wt} \% \mathrm{AP}$ after autoclaving at $200^{\circ} \mathrm{C}$ and $300^{\circ} \mathrm{C}$. Figure 6 depicts the XRD traces, $2 \theta$ degree, ranging from 3 to 51 , for the powder samples of $200^{\circ} \mathrm{C}$-auto-

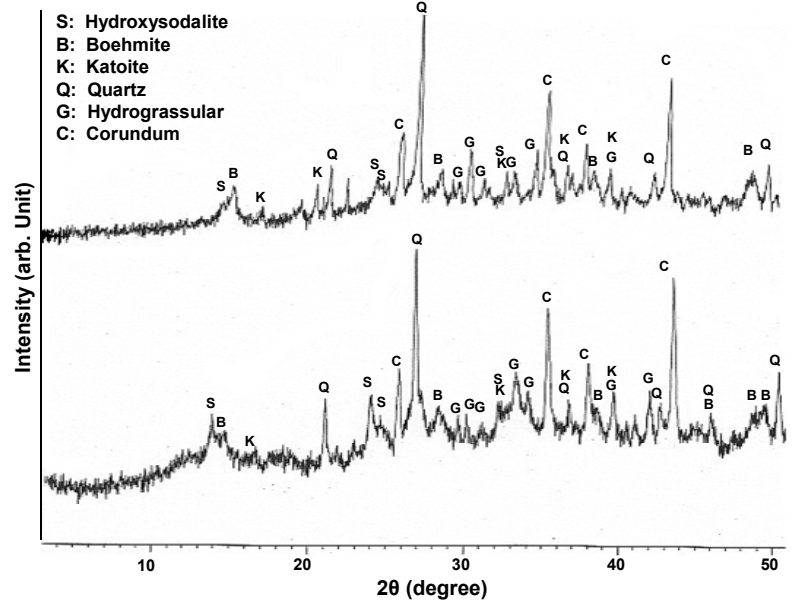

Figure 6. XRD patterns for $200^{\circ} \mathrm{C}$-autclaved foamed cements containing 0 (bottom) and $2 \%$ AP (top).

claved foamed cements with and without AP. For APfree foamed cement, the XRD pattern (bottom) showed that the cement was composed of the four crystalline hydration reaction products, hydroxysodalite

$\left[\mathrm{Na}_{4} \mathrm{Al}_{3} \mathrm{Si}_{3} \mathrm{O}_{12}(\mathrm{OH})\right]$, boehmite $(\gamma-\mathrm{AlOOH})$, Si-free katoite $\left[\mathrm{Ca}_{5} \mathrm{Al}_{2}(\mathrm{OH})_{12}\right]$, and intermediate hydrogrossular $\left[\mathrm{Ca}_{3} \mathrm{Al}_{2} \mathrm{Si}_{2} \mathrm{O}_{8}(\mathrm{OH})_{4}\right]$ phases, and two non-reacted crystalline products, quartz $\left(\mathrm{SiO}_{2}\right)$ and corundum $\left(\alpha-\mathrm{Al}_{2} \mathrm{O}_{3}\right)$. The quartz originated from the Class $\mathrm{F}$ fly ash, while corundum came from CAC. The boehmite and Si-free katoite phases were categorized as the hydration reaction products of CAC. Since the dissolution of sodium metasilicate activator in water generated two major hydrolysate reactants, sodium hydroxide, $\mathrm{NaOH}$, and metasilicic acid, $\mathrm{H}_{2} \mathrm{SiO}_{3}$ (and its sodium salt), the hydroxysodalite in the family of zeolite, was formed by the hydrothermal reactions between sodium hydroxide and mullite

$\left(3 \mathrm{Al}_{2} \mathrm{O}_{3} \cdot 2 \mathrm{SiO}_{2}\right)$ in Class $\mathrm{F}$ fly ash. On the other hand, the hydrothermal reactions between CAC and quartz in Class $\mathrm{F}$ fly ash led to the formation of hydrogrossular phases. Both hydrogrossular and Si-free katoite phases are in the hydrogarnet family. After modifying this cement with 2 $\mathrm{wt} \%$ AP, the XRD patterns (top) closely resembled that of AP-free one, suggesting that the AP had no significant effect upon the final phase composition assembled in the $200^{\circ} \mathrm{C}$-autoclaved foamed cement. Thus, relating this finding to the result of compressive strength at $200^{\circ} \mathrm{C}$, the improvement of this strength engendered by adding AP depended on the content of AP, but was independent of the phase composition.

Figure 7 illustrates the XRD tracings of $300^{\circ} \mathrm{C}$-autoclaved foamed cements with and without AP. Without $\mathrm{AP}$, there were two major differences in this XRD pattern (bottom) from that of the cement made at $200^{\circ} \mathrm{C}$.

First, the intensity of $d$-spacing lines related to quartz considerably decayed, implying that most of it in Class F 


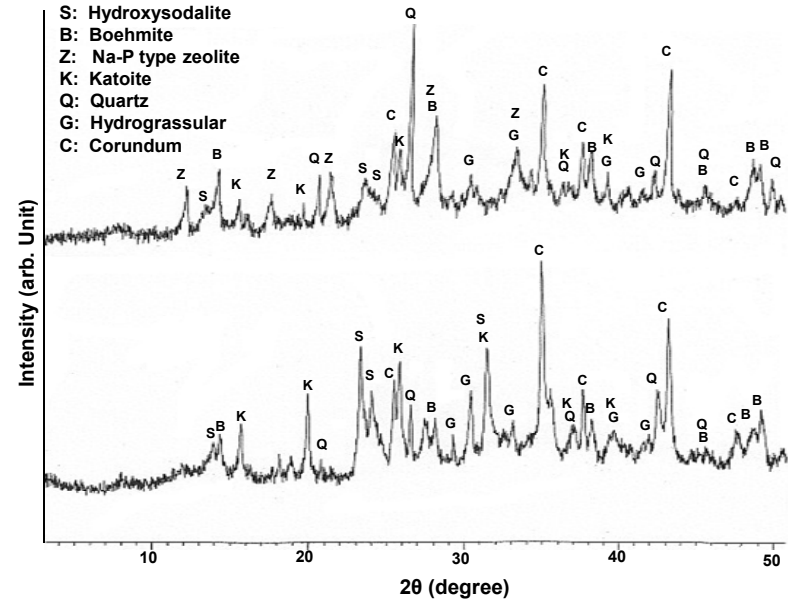

Figure 7. XRD patterns for $300^{\circ} \mathrm{C}$-autclaved foamed cements containing 0 (bottom) and $2 \%$ AP (top).

fly ash hydrothermally reacted with the other cementforming reactants. Second, intensive $d$-spacing lines were observed from hydroxysodalite, katoite, and hydrogrossular hydration products, emphasizing that these products were well crystallized at $300^{\circ} \mathrm{C}$ and became the major crystalline phases in conjunction with the corundum.

We interpreted these results as follows: Since the katoite phase had no silicate, seemingly the hydration reaction of CAC at $300^{\circ} \mathrm{C}$ created a well-formed katoite. Also, this high temperature promoted the extent of hydrothermal reactions between sodium hydroxide and mullite to form a well-crystallized hydroxysodalite. The principal reason for the depletion of quartz was the formation of more hydrogrossular because of an extensive reaction of CAC with quartz in Class F fly ash.

As described in compressive strength testing, the $300^{\circ} \mathrm{C}$-autoclaved cements had a higher compressive strength than those autoclaved at $200^{\circ} \mathrm{C}$. Thus, good formation at $300^{\circ} \mathrm{C}$ of these three crystalline hydrate phases, hydroxysodalite, katoite, and hydrograssular, seems to be responsible for improving compressive strength.

Of particular interest was the XRD pattern (top) of $2 \%$ AP-modified cement, compared with that of unmodified one. The pattern of the former was characterized by having three distinctive features; 1) the incorporation of a new crystalline hydrate phase attributed to Na-P type zeolite into the cement, 2) the presence of intensive $d$ spacing related to non-reacted quartz, and 3) the expression of a relatively weak line intensity of hydroxysodalite-, katoite-, and hydrograssular-associated $d$-spacing. The last two results suggested that AP not only inhibited the reactions of quartz in Class F fly ash with CAC to form hydrogrossular, but also restrained the extent of crystallization of hydroxysodalite and katoite, while an additional zeolite phase belonging to Na-P type was introduced in $300^{\circ} \mathrm{C}$-autoclaved cement. Similar to the re- lationship between AP content and compressive strength at $200^{\circ} \mathrm{C}$, the improvement of compressive strength at $300^{\circ} \mathrm{C}$ depended primarily on the AP content, but not on the crystalline phases and their composition.

Our attention next shifted to exploring the microstructure developed in the foamed cement with AP. Figure 8 shows the SEM images for the fractured surfaces of foamed cements without and with $2 \mathrm{wt} \%$ AP after autoclaving at $200^{\circ} \mathrm{C}$. Without AP, the image of the foamed cement made by incorporating numerous air bubbles into the slurry revealed a typical honeycomb-like porous structure encompassing craters of $\sim 300$ to $\sim 50 \mu \mathrm{m}$. Most of these craters had a partially defective structure, which can be interpreted as the formation of continuous voids. After modifying the cement with $2 \mathrm{wt} \% \mathrm{AP}$, the image was characterized by much smaller-size creators. Additionally, the defects in individual creators were minimal, implying that AP aided in forming defect-free small craters as discrete voids. A similar microstructure was apparent from the fractured surfaces of $300^{\circ} \mathrm{C}$-autoclaved foamed cements with and without AP (not shown).

Unlike the continuous voids-containing porous structure in the foamed cement, we can assume that the structure assembled by discrete voids would reduce the rates of permeability and transportation of corrosive electrolytes through the cement, assuring its ability to protect carbon steel (CS) against corrosion.

\subsection{Corrosion Mitigation}

To verify the potential of AP to mitigate the corrosion of CS, we conducted two electrochemical corrosion studies.

The first study centered on investigating the resistance of AP to the infiltration and transportation of a corrosive electrolyte through the foamed cement layer covering the underlying CS surface; and, the second one was to survey the effectiveness of AP in preventing the corrosion of CS at its interface with the foamed cement. The latter

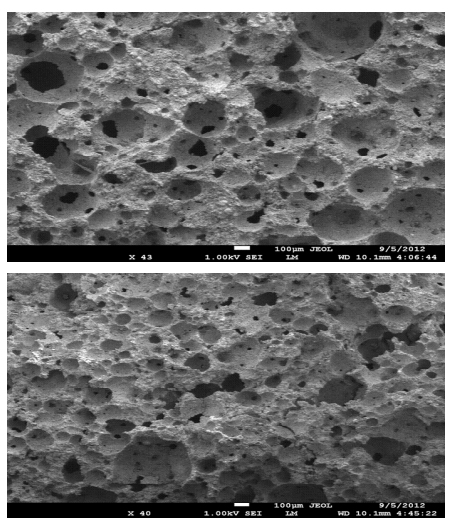

Figure 8. SEM images for fractured surfaces of foamed cements without AP (top) and 2 wt $\%$ AP-modified foamed cement (bottom). 
study also involved assessing the extent of coverage of CS surface by cement and the degree of cathodic corrosion protection along with the corrosion rates of CS. Another important factor in such protection was the adherence of coating to CS [12].

\subsubsection{EIS Test}

One major parameter governing the mitigation of corrosion by the cements is their conductivity of corrosive electrolytes; the extent of uptake of electrolytes by the cements plays a pivotal role in inhibiting or accelerating the corrosion of the underlying CS casing. We determined the extent of conductivity and transportation of ionic electrolytes through the cement layer to the underlying CS surfaces using EIS. The samples for EIS testing were prepared in the following manner: First, alkalinecleaned CS coupons were dipped in a soaking bath containing AP-modified or unmodified foamed cement slurry at room temperature; second, after withdrawing them, the slurry-covered coupons were left for 24 hours at room temperature, allowing the slurry layer to convert into a solid layer; third, the cured cement layer-coated CS was autoclaved for 24 hours at $200^{\circ} \mathrm{C}$ and $300^{\circ} \mathrm{C}$; and, finally, the autoclaved cement-covered CS coupon was left at room temperature to cool before EIS testing. Afterward, the coated CS coupon was mounted in a holder, and then inserted into a flat electrochemical cell. The coated coupon with a surface area of $13 \mathrm{~cm}^{2}$ was exposed to aerated $1.0 \mathrm{M}$ sodium chloride electrolyte at $25^{\circ} \mathrm{C}$ for $10 \mathrm{~min}$ before the EIS test.

Figure 9 compares the Bode-plot features [the absolute value of impedance $|\mathrm{Z}|\left(\mathrm{ohm}-\mathrm{cm}^{2}\right)$ vs. frequency $(\mathrm{Hz})]$ of the coupons coated with the non-foamed and foamed cements without AP. Particular attention in the overall EIS curves was paid to the pore resistance, $R_{p}$, which can be determined from the peak in the Bode-plot

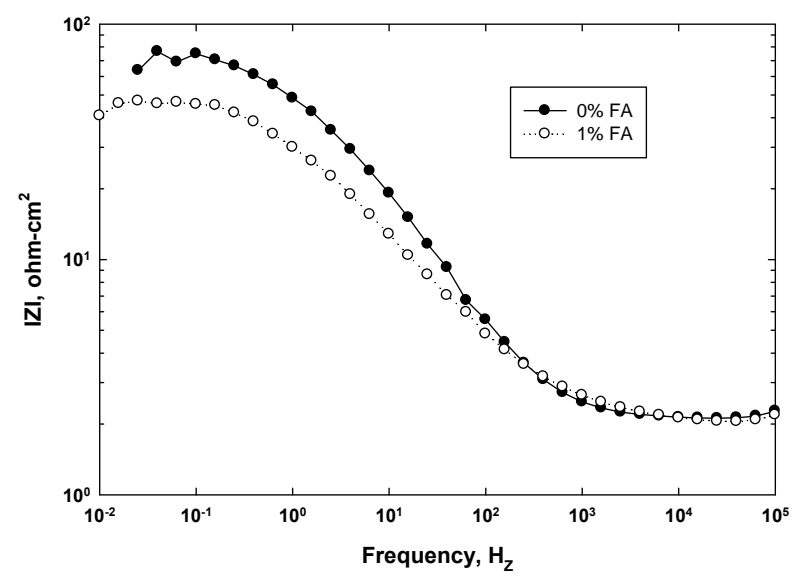

Figure 9. AC electrochemical impedance curves for nonfoamed and foamed cements without AP after autoclaving at $200^{\circ} \mathrm{C}$. occurring at a low frequency between $10^{-1}$ and $10^{-2} \mathrm{~Hz}$. For the non-foamed cement coating, the $R_{p}$ value was $76.5 \mathrm{ohm}-\mathrm{cm}^{2}$. This value reduced by nearly $53 \%$ to a $35.5 \mathrm{ohm}-\mathrm{cm}^{2}$, when this coating was foamed. Since the $R_{p}$ value reflects the extent of ionic conductivity generated by the $\mathrm{NaCl}$ electrolyte passing through the coating layer, this reduction represented an increase in the uptake of electrolytes by the coating. In other words, the foamed coating displayed poorer resistance to the infiltration and transportation of electrolyte through its layer than did the non-foamed coating.

Figure 10 depicts the changes in pore resistance, $R_{p}$, of $200^{\circ} \mathrm{C}$ - and $300^{\circ} \mathrm{C}$-autoclaved foam cements as a function of AP content. For the foamed cements without AP, the value of $R_{p}$ at $200^{\circ} \mathrm{C}$ rose with an increasing autoclave temperature to $300^{\circ} \mathrm{C}$, from 35.3 to $76.5 \mathrm{ohm}-\mathrm{cm}^{2}$. This fact strongly demonstrated that the coating's efficacy as corrosion-preventing barrier layer formed in an autoclave at $200^{\circ} \mathrm{C}$ was improved when autoclaved at $300^{\circ} \mathrm{C}$. As discussed under the compressive strength testing, the bulk density of $300^{\circ} \mathrm{C}$-autoclaved cement was higher than that of $200^{\circ} \mathrm{C}$-cement. Thus, we assumed that a densified structure of cement at $300^{\circ} \mathrm{C}$ was one of the factors affecting the abatement of the infiltration and transportation rates of corrosive electrolytes through it.

Incorporating AP into the $200^{\circ} \mathrm{C}$ - and $300^{\circ} \mathrm{C}$-autoclaved foamed cement coatings increased the $R_{p}$ value; this increase depended on the amount of AP. For instance, at $200^{\circ} \mathrm{C}$, the $R_{p}$ value of AP-free coating rose by $14 \%$ to $40.1 \mathrm{ohm}-\mathrm{cm}^{2}$ after adding $0.5 \mathrm{wt} \%$ AP. Adding $2 \mathrm{wt} \%$ AP markedly enhanced its value to $60.5 \mathrm{ohm}-\mathrm{cm}^{2}$, corresponding to $\sim 70 \%$ higher resistance than that of APfree coating. In other words, AP additive decreased the uptake of corrosive electrolytes by coating layer and suppressed the infiltration and transportation of electrolytes through it. Relating these findings to the results from our study of microstructure development, there

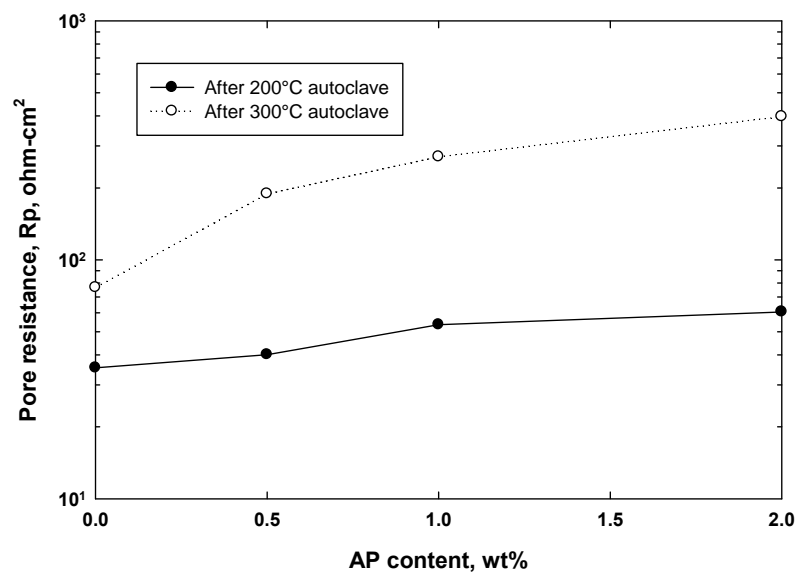

Figure 10. Changes in pore resistance of $200^{\circ} \mathrm{C}$ - and $300^{\circ} \mathrm{C}$ autoclaved foamed cements as a function of AP content. 
were two possible mechanisms for decreasing the rate of electrolyte infiltration through the foamed cement by AP: One was creation of porous structure composed of defect-free discrete voids; the other was related to the insitu formation of an electrolyte-impervious AP film in the foamed cement. Such contributions by AP played an essential role in improving the corrosion mitigation of CS by the foamed cement.

For the $300^{\circ} \mathrm{C}$-autoclaved coatings, the $R_{p}$ - $\mathrm{AP}$ content relation was similar to that of the coatings at $200^{\circ} \mathrm{C}$; namely, $R_{p}$ value rose with an increasing AP content. However, the rate of this increase brought about by adding AP was far greater than at $200^{\circ} \mathrm{C}$. A $397.3 \mathrm{ohm}-\mathrm{cm}^{2}$ detected with $2 \mathrm{wt} \%$ AP was 5.2-fold higher than that of the AP-free one at the same autoclave temperature. Compared with this, at $200^{\circ} \mathrm{C}$, the resistance increase by $2 \mathrm{wt} \%$ AP was only 1.7 -fold. This finding not only highlighted an excellent hydrothermal stability of AP at temperatures up to $300^{\circ} \mathrm{C}$, but also demonstrated that the hydrothermal temperature of $300^{\circ} \mathrm{C}$ aided AP in displaying a better performance in a pronounced reduction of the electrolyte's uptake by coating, compared with that at $200^{\circ} \mathrm{C}$. As is described in FT-IR study, the transformation of the acrylic acid and alkyl ester within AP into a hydrothermally stable M-complexed carboxylate structure was accelerated with an increasing hydrothermal temperature, underscoring that incorporating more AP would result in the formation and distribution of a large number of complexed carboxylate structures in the foamed cement. Thus, there were two possible reasons for an enhanced pore resistance of $300^{\circ} \mathrm{C}$-autoclaved foamed cement: One was the creation of a dense cement structure; the other was that such a complexed molecular structure served as barrier layers controlling the transportation rate of electrolytes through the foamed cement.

\subsubsection{Potentiodynamic Polarization Test}

For this test, we prepared the samples in the same manners as those employed in the EIS test. Figure 11 illustrates the typical cathodic-anodic polarization curves where the potential voltage, $E$, is plotted versus current density, $\mathrm{A} / \mathrm{cm}^{2}$, for $\mathrm{CS}$ coupons covered with the $200^{\circ} \mathrm{C}$ autoclaved foamed cements unmodified and modified with $2 \mathrm{wt} \%$ AP. The shape of the curve reveals the transition from cathodic polarization region at the onset of the most negative potential to the anodic polarization region at the end of the test at a less negative potential. The potential at the transition point from cathodic to anodic is normalized as the corrosion potential, $E_{\text {corr }}$. Compared with the features of the curve from AP-free foamed cement denoted as $0 \% \mathrm{AP}$, there were two noticeable differences for the CS coated with $2 \mathrm{wt} \%$ AP-modified cements: One was a shift in the $E_{\text {corr }}$ value to a less negative potential; the other was the reduction of cathodic

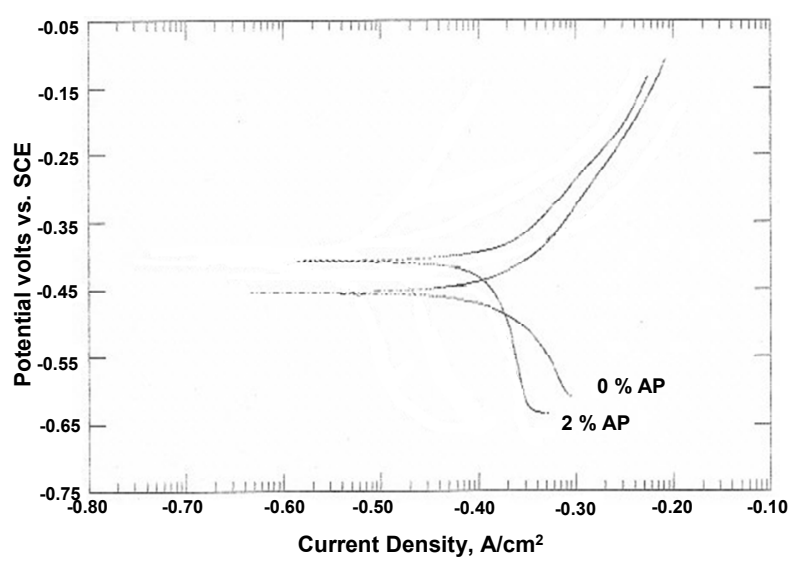

Figure 11. DC electrochemical potentiodynamic cathodicanodic polarization diagrams for foamed cements unmodified and modified with $2 \%$ AP after autoclaving at $200^{\circ} \mathrm{C}$.

current density $\left(\mathrm{A} / \mathrm{cm}^{2}\right)$ between -0.6 and $-0.7 \mathrm{~V}$. The first difference reflects the extent of cement coverage of the CS surface; namely, a good coverage by a continuous void-free coating layer at the contact zones with CS surface is responsible for moving the $E_{\text {corr }}$ value to a less negative potential. This shift of $E_{\text {corr }}$ underscored that adding $2 \%$ AP increased the extent of coverage by the foamed cements. For the second difference, the decline in the cathodic current density signified that the cathodic reaction at the corrosion site of CS was restrained, particularly the oxygen reduction reaction, $2 \mathrm{H}_{2} \mathrm{O}+\mathrm{O}_{2}+4 \mathrm{e}^{-}$ $\rightarrow 4 \mathrm{OH}^{-}$. Correspondingly, such a reaction leading to the cathodic corrosion of CS appeared to be inhibited by depositing the AP-modified foamed cement on the CS surfaces, thereby highlighting the ability of AP to abate the corrosion of CS. Thus, AP conferred two advanced corrosion-mitigating properties on the foamed cements for providing a better protection of CS against brinecaused corrosion: First, it afforded a better coverage of cement over the steel surfaces; second was its efficacy in upgrading the ability of cement to inhibit the cathodic corrosion reaction of CS.

Based upon the potentiodynamic polarization curve (Figure 12), we determined the absolute corrosion rates of CS, expressed in the conventional engineering units of milli-inches per year (mpy). The Equation (1) proposed by Stern and Geary [13] was used in the first step:

$$
I_{\text {corr }}=\beta_{a} \cdot \beta_{c} / 2.303\left(\beta_{a}+\beta_{c}\right) P_{R}
$$

In the equation the $I_{c o r r}$ is the corrosion current density in $\mathrm{A} / \mathrm{cm}^{2} ; \beta_{a}$ and $\beta_{c}$ in $\mathrm{V} /$ decade of current refer to the anodic and cathodic Tafel slops, respectively, obtained from the $\log I$ vs. $E$ plots encompassing both anodic and cathodic regions; and, $P_{R}$ is the polarization resistance determined from the corrosion potential, $E_{\text {corr }}$. With $I_{\text {corr }}$ computed through Equation (1), the corrosion rate (mpy) can be obtained from the following expression: 
Corrosion rate $=0.13 I_{\text {corr }}(\mathrm{EW}) / d$; where $\mathrm{EW}$ is the equivalent weight of the corroding CS in g; and $d$ is the density of the corroding CS in $\mathrm{g} / \mathrm{cm}^{3}$. Table 3 gives the $I_{\text {corr }}$ and corrosion rate calculated for CS panels coated with unmodified and modified with AP cement after autoclaving at $200^{\circ}$ and $300^{\circ} \mathrm{C}$ for 24 hours. For the $200^{\circ} \mathrm{C}$-autoclaved test panels, the corrosion rate of the CS for AP-free coating was 175.7 mpy with accompanying $I_{\text {corr }}$ of $38.5 \times 10^{-5} \mathrm{~A} / \mathrm{cm}^{2}$. These values conspicuously dropped to 68.9 mpy and $15.07 \times 10^{-5} \mathrm{~A} / \mathrm{cm}^{2}$ when the cement was modified with $2 \% \mathrm{AP}$, clearly validating the effectiveness of the AP in mitigating the CS's corrosion and in resisting the cathodic corrosion reactions.

A very interesting data on corrosion mitigation was obtained from the $300^{\circ} \mathrm{C}$-autoclaved test panels; namely, the CS's corrosion rate of $43.1 \mathrm{mpy}$ and $I_{\text {corr }}$ value of $9.42 \times 10^{-5} \mathrm{~A} / \mathrm{cm}^{2}$ by AP-free foamed cement was considerably lower than those of the $200^{\circ} \mathrm{C}$-autoclaved APfree one. This corrosion rate represented nearly a 4-fold reduction compared with that of $200^{\circ} \mathrm{C}$; correspondingly, the similar reduction was observed in the $I_{\text {corr }}$ value, suggesting that the foamed cement autoclaved at $300^{\circ} \mathrm{C}$

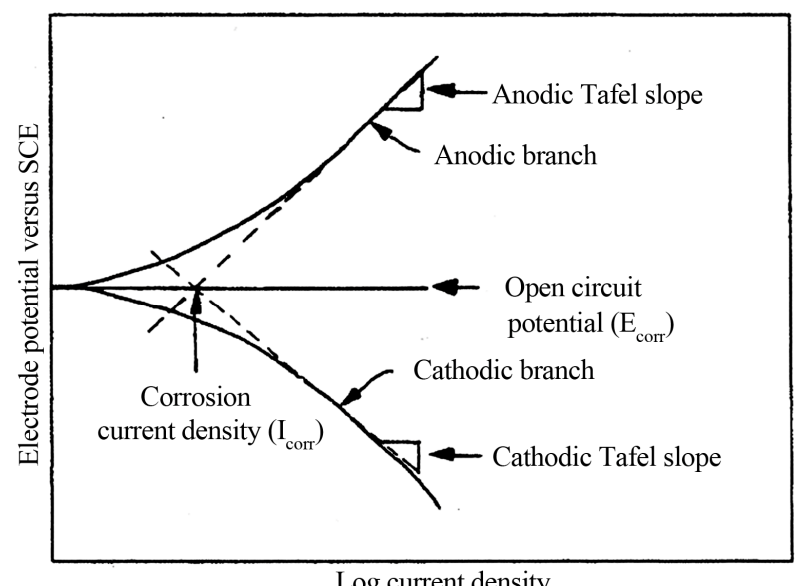

Figure 12. Typical Tafel plot from a polarization experiment. displayed a better performance in inhibiting the carthodic reaction and mitigating the CS's corrosion. A further reduction of both the corrosion rate and $I_{\text {corr }}$ value was realized by adding AP to it; in fact, a $2 \%$ AP provided a very low corrosion rate and $I_{\text {corr }}$ value of $6.8 \mathrm{mpy}$ and $1.49 \times 10^{-5} \mathrm{~A} / \mathrm{cm}^{2}$, respectively, reflecting 6.3-fold lowering over those of AP-free cement. This finding also verified that AP not only withstood exposure to a hydrothermal environment at $300^{\circ} \mathrm{C}$, but also improved $\mathrm{CS}$ protection against brine-caused corrosion by $300^{\circ} \mathrm{C}$ autoclaved foamed cement.

Hence, AP had a potential as a high-temperature corrosion-inhibiting additive responsible for mitigating the CS's corrosion at temperatures up to $300^{\circ} \mathrm{C}$.

\subsubsection{Adherence of Foamed Cement to CS}

Since a better interfacial bond between coating and CS was another factor governing the alleviation of the CS's corrosion, we evaluated the extent of adherence of the $200^{\circ} \mathrm{C}$ and $300^{\circ} \mathrm{C}$-autoclaved foamed cements modified with $0,0.5,1.0$, and $2.0 \mathrm{wt} \%$ AP to CS surfaces by $\mu$ EDX-elemental mapping and -oxide quantitative analysis.

The samples were prepared in the following sequences: First, the CS coupons' surfaces were coated with AP-modified and unmodified foamed cements; second, the coated CS coupons were autoclaved at $200^{\circ} \mathrm{C}$ or $300^{\circ} \mathrm{C}$ for 24 hours; third, the autoclaved coupons were placed on the center-loading bending apparatus to generate the tensile shear-bonding failure at the side of cement coating of CS, leading to the delamination of cement layer from underlying CS surface; and fourth, the CS side separated from the cement layer was used for the $\mu$ EDX mapping and the quantitative analysis of metal oxides. Assuming the cement adhered well to CS surfaces and the failure of interfacial bonding occurs in cement layers, our attention centered on obtaining the following information: One was to visualize the distribution of cement-related $\mathrm{Ca}, \mathrm{Al}$, and $\mathrm{Si}$ elements remained

Table 3. Tafel analyses of potentiodynamic polarization curves for steel panels covered with AP-modified and unmodified foamed cements.

\begin{tabular}{|c|c|c|c|c|c|c|}
\hline Temperature, ${ }^{\circ} \mathrm{C}$ & AP content, wt $\%$ & $E_{\text {corr }}(\mathrm{I}=0),(\mathrm{V})$ & $\beta_{a},($ V/decade $)$ & $\beta_{c},(\mathrm{~V} /$ decade $)$ & $I_{c o r r},\left(\mathrm{~A} / \mathrm{cm}^{2}\right)$ & Corrosion rate, $(\mathrm{mpy})^{*}$ \\
\hline 200 & 0 & -0.4551 & 0.2556 & 0.3814 & $38.50 \times 10^{-5}$ & 175.7 \\
\hline 200 & 2.0 & -0.4099 & 0.1623 & 0.6835 & $15.07 \times 10^{-5}$ & 68.9 \\
\hline 300 & 0 & -0.3226 & 0.1562 & 0.2756 & $9.42 \times 10^{-5}$ & 43.1 \\
\hline 300 & 0.5 & -0.4668 & 0.0955 & 0.3224 & $7.03 \times 10^{-5}$ & 32.1 \\
\hline 300 & 1.0 & -0.3128 & 0.2046 & 0.4188 & $4.29 \times 10^{-5}$ & 19.6 \\
\hline 300 & 2.0 & -0.3414 & 0.1700 & 0.3136 & $1.49 \times 10^{-5}$ & 6.8 \\
\hline
\end{tabular}

*mpy: milli-inches per year. 
over the separated CS surfaces; the other was the changes in the content of metal oxides, in particular, $\mathrm{Fe}_{2} \mathrm{O}_{3}, \mathrm{CaO}$, $\mathrm{Al}_{2} \mathrm{O}_{3}$, and $\mathrm{SiO}_{2}$, as a function of $\mathrm{AP}$ content. Thus, if we observed a widespread distribution of these elements and a great deal of these oxides, a possible interpretation was that the cement was well adhered to CS surfaces.

Also, it should be noted that since the penetration depth of X-ray from $\mu \mathrm{EDX}$ is $\sim 2 \mu \mathrm{m}$, all data related to elemental mapping and oxide compositions came from a top $\sim 2 \mu \mathrm{m}$ thick surface layer.

Figure 13 represents the individual $\mu \mathrm{EDX}$ maps of $\mathrm{Fe}$ and $\mathrm{Ca}$ elements for $\mathrm{CS}$ surface separated from the $200^{\circ} \mathrm{C}$ - and $300^{\circ} \mathrm{C}$-autoclaved AP-free foamed cement layers. The $\mu \mathrm{EDX}$ analyses were conducted on the mapping areas of $4.0 \times 3.0 \mathrm{~mm}\left(12 \mathrm{~mm}^{2}\right)$ and targeted for detecting the two specific elements, Fe belonging to underlying $\mathrm{CS}$ and $\mathrm{Ca}$ attributed to cement. During the mapping operation, X-ray intensities of 6.4 and $3.7 \mathrm{keV}$ lines for $\mathrm{Fe} K \alpha$ and $\mathrm{Ca} K \alpha$ respectively were recorded and used for creating color-coded maps of their relative distribution. The maximum amount, in percent, of each tested element is given above the color-barcode. Further, the concentration of these elements is ranked by the difference in colors; namely, the area in white color coding indicates the highest concentration of these elements present on the CS surfaces, the dark red color is their secondary concentrated areas, while no presence or negligible amount of these elements is signified by the areas in the darkest blue color. Correspondingly, the greenish and yellowish colors reflect a moderate presence of these elements. For the $200^{\circ} \mathrm{C}$-autoclaved foamed cement, the elemental mapping of $\mathrm{Fe}$ revealed mainly two different regions on the CS surface: One was the top- and bottom-central regions representing the distributions of the
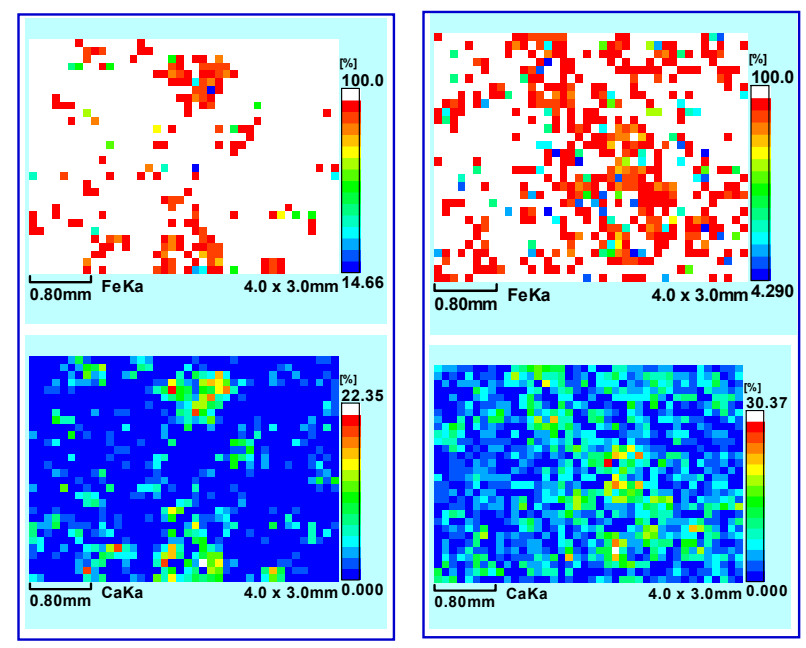

Figure 13. EDX elemental mapping of Fe (top) and Ca (bottom) for interfacial CS sides separated from AP-free foamed cements after autoclaving at $200^{\circ} \mathrm{C}$ (left) and $300^{\circ} \mathrm{C}$ (right). red signal as major color code, and some green signal as well as blue signal as minor one; the other was the rest of this detected area, which mostly was white. The last result meant that this region was dominated by Fe element originating from the underlying CS, implying no or poor converge of CS surface by any other elements. In contrast, the former region was covered by some different elements. Hence, although the amount of $\mathrm{Ca}$ was only $22.4 \%$ at maximum on the studied area, Ca mapping exhibited some presence of this element over the top- and bottom-central regions, signifying that some cement remained locally on the CS surface separated from the cement layer. This Ca-presence increased to $30.4 \%$, when the foamed cement was autoclaved at $300^{\circ} \mathrm{C}$. In fact, as seen in Fe map, a large area over the CS surface was covered by other elements coexisting with $\mathrm{Fe}$, compared with that of $200^{\circ} \mathrm{C}$-autoclaved foamed cement/CS interface sample. This finding demonstrated that the climbing the temperature to $300^{\circ} \mathrm{C}$ from $200^{\circ} \mathrm{C}$ improved the adherence of the foamed cement to CS.

Figure 14 gives the $\mu \mathrm{EDX}$ mapping results of four elements, $\mathrm{Fe}, \mathrm{Ca}, \mathrm{Al}$, and $\mathrm{Si}$ for the interfacial CS dislodged from the $1.0 \mathrm{wt} . \%$ AP-modified foamed cement layer after autoclaving the cement/CS sample at $300^{\circ} \mathrm{C}$. $\mathrm{X}$-ray intensity counts of $\mathrm{Al}$ and $\mathrm{Si}$ were taken from $\mathrm{Al}$ $K \alpha$ and $\mathrm{Si} K \alpha$ at 1.5 and $1.7 \mathrm{keV}$, respectively.

When the configuration of Fe mapping was compared with that of $\mathrm{Ca}$ over the CS surfaces, the distribution pattern of these two elements were very similar; thus, the highly concentrated region of Fe marked as the whitecolor code was directly opposite to the lowest concentration region of $\mathrm{Ca}$ (dark blue). In contrast, although a high amount of $93.8 \%$ and $72.3 \%$ was detected for $\mathrm{Al}$ and $\mathrm{Si}$, respectively, the configuration of their mapping images was quite distinct from those of $\mathrm{Fe}$ and $\mathrm{Ca}$.

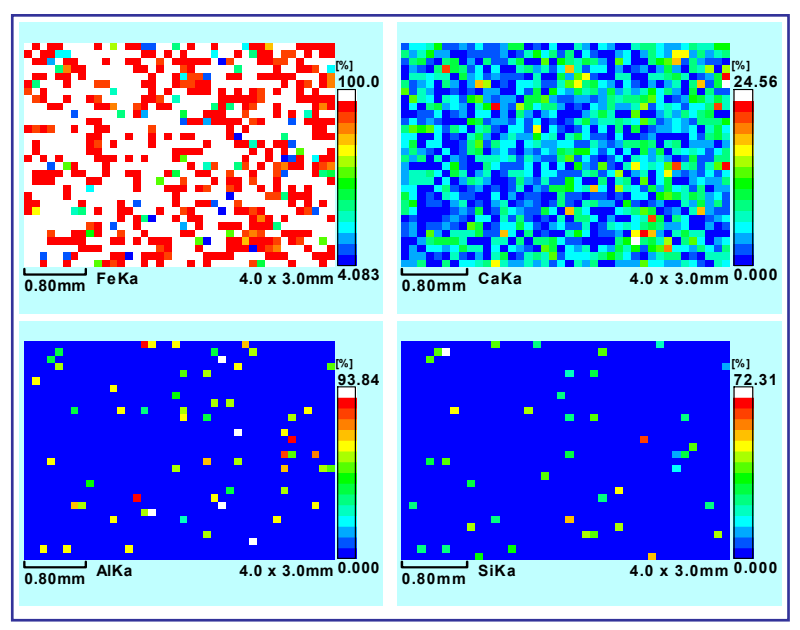

Figure 14. Comparison of $\mathrm{Fe}, \mathrm{Ca}, \mathrm{Al}$, and $\mathrm{Si}$ elemental mapping images for interfacial CS surfaces dislodged from the $1.0 \mathrm{wt} \%$ AP-modified foamed cement after autoclaving at $300^{\circ} \mathrm{C}$. 
A possible interpretation of this finding was that $\mathrm{Ca}$ preferentially reacted with $\mathrm{CS}$ surfaces, rather than $\mathrm{Al}$ and Si. Similar results were observed from all tested panels with and without AP after autoclaving at $200^{\circ} \mathrm{C}$ and $300^{\circ} \mathrm{C}$.

Next, we investigated the effectiveness of AP in improving the adherence of foamed cement to the $\mathrm{CS}$ at $200^{\circ} \mathrm{C}$ and $300^{\circ} \mathrm{C}$. Using $\mu \mathrm{EDX}$, our approach to obtaining this information was made by tracing the contents of oxide compounds such as $\mathrm{Fe}_{2} \mathrm{O}_{3}, \mathrm{CaO}, \mathrm{Al}_{2} \mathrm{O}_{3}$, and $\mathrm{SiO}_{2}$, as a function of AP content, for the interfacial CS surface.

Thus, a high content of three cement-related oxides, $\mathrm{CaO}, \mathrm{Al}_{2} \mathrm{O}_{3}$, and $\mathrm{SiO}_{2}$, on CS surface, we judged as good cement coverage of the $\mathrm{CS}$, and an excellent adherence of cement to CS.

Figure 15 reveals the concentrations of oxides on CS for $200^{\circ} \mathrm{C}$-autoclaved foamed cements containing $0,0.5$, $1.0,1.5$, and $2.0 \mathrm{wt} \%$ AP. Without AP, the composition of oxides was $92.8 \% \mathrm{Fe}_{2} \mathrm{O}_{3}, 1.3 \% \mathrm{CaO}, 0.0 \% \mathrm{Al}_{2} \mathrm{O}_{3}$, and, $7.1 \% \mathrm{SiO}_{2}$, revealing that some $\mathrm{Ca}$ and $\mathrm{Si}$ oxides related to cement were deposited on CS. Adding 0.5\% AP to cement increased the content of $\mathrm{CaO}$ and $\mathrm{SiO}_{2}$, to $2.1 \%$ and $8.8 \%$, respectively. A further increase in $\mathrm{Ca}$ and $\mathrm{Si}$ oxides to $3.6 \%$ and $10.9 \%$ was detected for $2.0 \%$ AP, while the CS-related $\mathrm{F}_{2} \mathrm{O}_{3}$ content declined with an increasing AP content. Of particular interest in the deposition of cement-related oxides on CS was $\mathrm{Al}_{2} \mathrm{O}_{3}$; its deposition began at $1.0 \mathrm{wt} \% \mathrm{AP}$, beyond that, at $2.0 \mathrm{wt} . \% \mathrm{AP}$ the deposition was $13.6 \% \mathrm{Al}_{2} \mathrm{O}_{3}$, which was the highest content, among these cement-related oxides. Thus, the incorporation of more AP into foamed cement not only assured the extensive coverage of cement over the CS, so representing the improved adherence of cement to $\mathrm{CS}$, but also led to the formation of $\mathrm{Al}_{2} \mathrm{O}_{3}$-rich cement layer adhering to the CS.

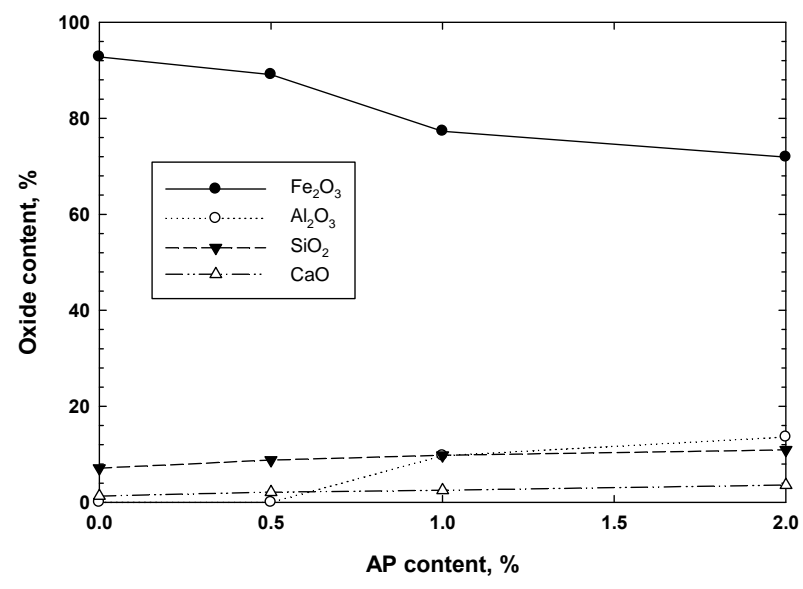

Figure 15. Changes in the content of oxides present at interfacial CS surface as a function of AP content for $200^{\circ} \mathrm{C}$ autoclaved cement/CS samples.
For the $300^{\circ} \mathrm{C}$-autoclaved cement/CS samples (Figure 16), the oxide composition of interfacial CS surfaces was $80.6 \% \mathrm{Fe}_{2} \mathrm{O}_{3}, 2.5 \% \mathrm{CaO}, 0.0 \% \mathrm{Al}_{2} \mathrm{O}_{3}$, and, $16.9 \% \mathrm{SiO}_{2}$. Like, in the $200^{\circ} \mathrm{C}$-autoclaved sample without $\mathrm{AP}$, no $\mathrm{Al}_{2} \mathrm{O}_{3}$ was detected on the $\mathrm{CS}$ surface. However, the concentration of $\mathrm{Fe}_{2} \mathrm{O}_{3}$ was $\sim 13 \%$ lower than that of $200^{\circ} \mathrm{C}$-autoclaved sample.

Correspondingly, the concentrations of $\mathrm{CaO}$ and $\mathrm{SiO}_{2}$ rose by nearly 2 -fold the former oxide and 2.4-fold for the latter one, underscoring that the extent of the adherence of foamed cement to CS increased with the raising hydrothermal temperature to $300^{\circ} \mathrm{C}$. When the foamed cement was modified with $0.5 \% \mathrm{AP}$, the cement layer adhering to $\mathrm{CS}$ had a relatively high $\mathrm{Al}_{2} \mathrm{O}_{3}$ content of $20.5 \%$ coexisting with $3.5 \% \mathrm{CaO}$ and $18.2 \% \mathrm{SiO}_{2}$. The content of these oxides gradually rose with an increasing AP content, contrarily, the $\mathrm{Fe}_{2} \mathrm{O}_{3}$ content declined. With $2.0 \mathrm{wt} \%$ AP, a $44.9 \% \mathrm{Fe}_{2} \mathrm{O}_{3}$ detected corresponded to lowering of $\sim 22 \%$ from that of $0.5 \%$ AP, while the increase of $\sim 47 \%, \sim 10 \%$, and $\sim 37 \%$ was observed for all cement-related oxides, $\mathrm{Al}_{2} \mathrm{O}_{3}, \mathrm{CaO}$, and $\mathrm{SiO}_{2}$, respectively, implying that although the temperature was elevated to $300^{\circ} \mathrm{C}$, the $\mathrm{AP}$ was as effective in improving the adherence of foamed cement as was the case at $200^{\circ} \mathrm{C}$. Hence, the M-complexed AP compounds formed in $300^{\circ} \mathrm{C}$-autoclaved foamed cement withstood the hydrothermal temperature of $300^{\circ} \mathrm{C}$; they played an essential role in enhancing bonding of foamed cement to $\mathrm{CS}$, thereby resulting in the cohesive failure mode wherein interfacial bonding failure took place in the cement layer near the interface regions between CS and cement.

\section{Conclusion}

Air bubble-foamed cement (slurry density of $\leq 1.3 \mathrm{~g} / \mathrm{cm}^{3}$ ) consisting of refractory calcium aluminate cement (CAC), Class F fly ash, sodium silicate activator, and cocamido-

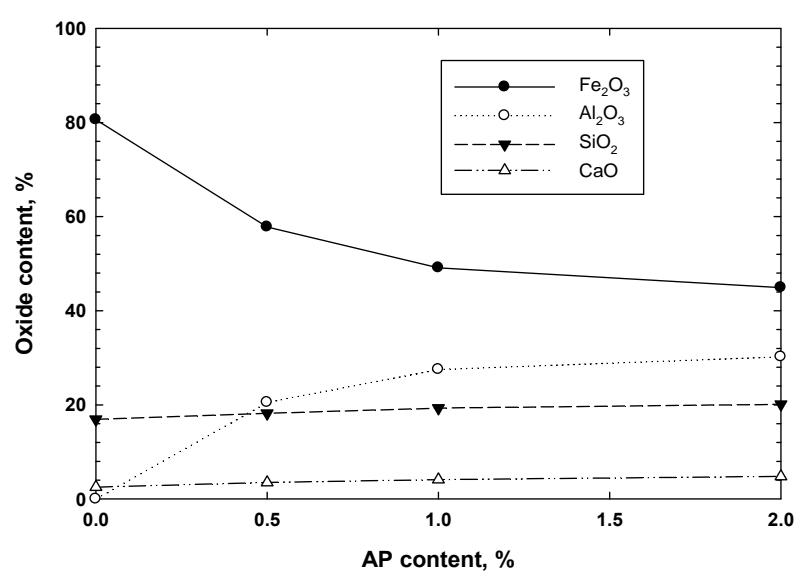

Figure 16. Changes in the content of oxides present at interfacial CS surface as a function of AP content for $300^{\circ} \mathrm{C}$ autoclaved cement/CS samples. 
propyl dimethylamine oxide-based foaming agent, was modified with acrylic polymer (AP) employed as a hightemperature cathodic corrosion inhibitor of carbon steel (CS) after exposure to the hydrothermal environment at $200^{\circ} \mathrm{C}$ or $300^{\circ} \mathrm{C}$. Under these conditions, the functional acrylic acid and alkyl ester groups within AP reacted with the metal cations (M), such as $\mathrm{Ca}^{2+}, \mathrm{Al}^{3+}$, and $\mathrm{Na}^{+}$, liberated from sodium silicate-activated CAC and Class $\mathrm{F}$ fly ash, leading to the formation of M-complexed carboxylate group-containing AP in the cement body at $\geq 85^{\circ} \mathrm{C}$. Such in-situ transformation of these functional groups into complexed groups progressively occurred as the hydrothermal temperature rose. This transformation improved the thermal stability of AP. Correspondingly, the complexed carboxylate-rich AP withstood a hydrothermal temperature at $300^{\circ} \mathrm{C}$, ensuring that $\mathrm{AP}$ as the corrosion inhibitor was capable of protecting the CS against corrosion at this temperature. Addition of AP delayed the onset of cement set while increasing the integrated heat released during cement hydration in calorimetric experiments at $85^{\circ} \mathrm{C}$.

At $200^{\circ} \mathrm{C}$, AP did not cause any significant changes of crystalline hydrate composition assembled in the AP-free foamed cement; namely, its composition comprised four hydrothermal hydration reaction products, hydroxysodalite $\left[\mathrm{Na}_{4} \mathrm{Al}_{3} \mathrm{Si}_{3} \mathrm{O}_{12}(\mathrm{OH})\right]$, intermediate hydrogrossular $\left[\mathrm{Ca}_{3} \mathrm{Al}_{2} \mathrm{Si}_{2} \mathrm{O}_{8}(\mathrm{OH})_{4}\right]$, boehmite $(\gamma-\mathrm{AlOOH})$, and Si-free katoite $\left[\mathrm{Ca}_{5} \mathrm{Al}_{2}(\mathrm{OH})_{12}\right]$ phases that were responsible for strengthening the $200^{\circ} \mathrm{C}$-autoclaved foamed cement. The hydroxysodalite phase was formed by hydrothermal interactions between the sodium silicate activator and mullite phase in Class F fly ash, while the quartz in Class F fly ash reacted with $\mathrm{CAC}$ to form hydrogrossular. On the other hand, hydration of CAC engendered two other phases, boehmite and Si-free katoite. Although, similar crystalline phases were formed in cement with and without AP, the compressive strength rose with an increasing AP content. At the hydrothermal temperature of $300^{\circ} \mathrm{C}$, the crystalline phases and their quantities differed from those observed at $200^{\circ} \mathrm{C}$. For AP-free cement, three phases, hydroxysodalite, katoite, and hydrogrossular, were well formed and crystallized; in particular, a substantial amount of quartz in Class F fly ash hydrothermally reacted with $\mathrm{CAC}$ to form more hydrogrossular. Consequently, these well-formed crystalline compounds aided in improving further the cement's compressive strength, compared with that at $200^{\circ} \mathrm{C}$. Adding AP restrained the formation of these three crystalline hydrate phases, while Na-P type zeolite was formed as additional crystalline phase. Like the findings at $200^{\circ} \mathrm{C}$, the development of compressive strength depended on AP content; namely, strength rose with an increasing AP content.

The microstructure developed in the autoclaved foamed cements was characterized by a honeycomb-like porous structure constituted of numerous defected micro-size craters. Adding AP conferred two beneficial alterations in this microstructure: First, the defected craters were transformed to defect-free discrete voids; and, second, the size of craters became much smaller. Thus, creating defect-free, small craters was one reason why the AP-modified foamed cements developed a good compressive strength. The other benefit from the presence of such advanced microstructure was the reduction of infiltration and transportation of corrosive electrolytes through the foamed cement layer, thereby mitigation of the corrosion of underlying CS.

We believe that the AP addition to the foamed cement significantly reduced corrosion rate of $\mathrm{CS}$ at the hydrothermal temperature of $300^{\circ} \mathrm{C}$ because of the following two key factors: the formation of $300^{\circ} \mathrm{C}$-withstanding barrier layers constituted of complexed carboxylate-rich AP and the improved adherence of the cement to CS surfaces. For the latter, incorporating more AP yielded a better cement adherence. Additionally, among the Ca-, $\mathrm{Si}$ - and Al-oxides in hydraulic cement, $\mathrm{Ca}$ oxide preferentially coupled to the $\mathrm{Fe}_{2} \mathrm{O}_{3}$ layer arrayed at the surface of CS at $200^{\circ} \mathrm{C}$. The coverage of CS surface by Ca oxide extended with an increasing temperature, resulting in better adherence of $300^{\circ} \mathrm{C}$-autoclaved cement to $\mathrm{CS}$, compared with that of $200^{\circ} \mathrm{C}$-autoclaved one. The following three important factors governed the mitigation of CS's corrosion: 1) Minimized conductivity of corrosive ionic electrolytes through the foamed cement layer; 2) inhibited cathodic reactions at corrosion site of CS; and 3) increased coverage of CS surface by a foamed-cement layer at the interfacial boundary regions between the cement and CS.

For AP-free foamed cements, the corrosion rate, 175 milli-inch per year (mpy), of CS after autoclaving at $200^{\circ} \mathrm{C}$, reduced by 4 times when the autoclaving temperature increased to $300^{\circ} \mathrm{C}$. For AP-modified foamed cements, the corrosion rate of CS coated with AP-free cement at $200^{\circ} \mathrm{C}$ fell 2.6 times with $2 \mathrm{wt} \%$ AP. At $300^{\circ} \mathrm{C}$, $2 \mathrm{wt} \%$ AP lowered conspicuously the CS's corrosion rate to only 6.8 mpy from 43 mpy for AP-free one.

\section{REFERENCES}

[1] S. Gill, T. Pyatina and T. Sugama, "Thermal Shock-Resistant Cement," Geothermal Resources Council Transaction, Vol. 36, 2012, pp. 445-451.

[2] T. Sugama L. E. Brothers and T. R. Van de Putte, "Air-Foamed Calcium Aluminate Phosphate Cement for Geothermal Wells," Cement and Concrete Composite, Vol. 27, No. 7-8, 2005, pp. 758-768. http://dx.doi.org/10.1016/j.cemconcomp.2004.11.003

[3] K. Y. Ann, H. S. Jung, H. S. Kim, S. S. Kim and H. Y. Moon, "Effect of Calcium Nitrite-Based Corrosion Inhibitor in Preventing Corrosion of Embedded Steel in 
Concrete," Cement and Concrete Research, Vol. 36, No. 3, 2006, pp. 530-535.

http://dx.doi.org/10.1016/j.cemconres.2005.09.003

[4] M. Saremi and E. Mahallati, "A Study on Chloride-Induced Depassivation of Mild Steel in Simulated Concrete Pore Solution," Cement and Concrete Research, Vol. 32, No. 12, 2002, pp. 1915-1921. http://dx.doi.org/10.1016/S0008-8846(02)00895-5

[5] P. Ghods, O. B. Isgor, G. A. McRae and G. P. Gu, "Electrochemical Investigation of Chloride-Induced Depassivation of Black Steel Rebar under Simulated Service Conditions," Corrosion Science, Vol. 52, 2010, pp. 16491659. http://dx.doi.org/10.1016/j.corsci.2010.02.016

[6] Y. M. Tang, Y. F. Miao, Y. Zuo, G. D. Zhang and C. L. Wang, "Corrosion Behavior of Steel in Simulated Concrete Pore Solutions Treated with Calcium Silicate Hydrates," Construction and Building Materials, Vol. 30, 2012, pp. 252-256.

http://dx.doi.org/10.1016/j.conbuildmat.2011.11.033

[7] A. R. Boga and I. B. Topcu, "Influence of Fly Ash on Corrosion Resistance and Chloride Ion Permeability of Concrete," Construction and Building Materials, Vol. 31, 2012, pp. 258-264. http://dx.doi.org/10.1016/j.conbuildmat.2011.12.106

[8] J. Hu, D. A. Koleva and K. van Breugel, "Corrosion Performance of Reinforced Mortar in the Presence of Polymeric Nano-Aggregates: Electrochemical Behavior, Surface Analysis, and Properties of the Steel/Cement Past
Interface," Journal of Material Science, Vol. 47, 2012, pp. 4981-4995. http://dx.doi.org/10.1007/s10853-012-6374-6

[9] S. X. Wang, W. W. Lin, S. A. Ceng and J. Q. Zhang, "Corrosion Inhibition of Reinforcing Steel by Using Acrylic Latex," Cement and Concrete Research, Vol. 28, 1998, pp. 649-653. http://dx.doi.org/10.1016/S0008-8846(98)00048-9

[10] R. Selvaraj, M. Selvaraj and S. V. K. Iyer, "Studies on the Evaluation of the Performance of Organic Coatings Used for the Prevention of Corrosion of Steel Rebars in Concrete Structure," Progress in Organic Coatings, Vol. 64, No. 4, 2009, pp. 454-459. http://dx.doi.org/10.1016/j.porgcoat.2008.08.005

[11] T. Sugama, "Hydrothermally Self-Advancing Hybrid Coatings for Mitigating Corrosion of Carbon Steel," Brookhaven National Laboratory, 2006, BNL-77335.

[12] P. R. Sere, A. R. Armas, C. I. Elsner and A. R. Di Sarli, "The Surface Condition Effect on Adhesion and Corrosion Resistance of Carbon Steel/Chlorinated Rubber/Artificial Sea Water Systems," Corrosion Science, Vol. 38, 1996, pp. 853-866. http://dx.doi.org/10.1016/0010-938X(96)00171-0

[13] M. Stern and A. L. Geary, "Electrochemical Polarization I. A Theoretical Analysis of the Shape of Polarization Curves," Journal of Electrochemical Society, Vol. 104, No. 1, 1975, pp. 56-62. http://dx.doi.org/10.1149/1.2428496 